cortical flow. This intrarenal blood flow is apparently sensitive to extrarenal stimuli as positive pressure ventilation causes a reversal of this flow. The direct application of this data to clinical conditions is difficult. However, these data suggest that low urine flow rates in human infants on ventilation might be secondary to local intrarenal blood flow changes induced by assisted ventilation.

\section{REFERENCES AND NOTES}

1. Behrman, R. E., and Lee, M. H.: Organ blood flows of the fetal, newborn and adult rhesus monkey. Biol. Neonate, 18: 330 (1971).

2. Bersentes, T. J., and Simmons, D. H.: Effects of acute acidosis on renal hemodynamics. Amer. J. Physiol., 212: 633 (1967).

3. Buckberg, G. D., Luck, J. C., Payne, D. B., Hoffman, J. I. E. Archie, J. P., and Fixler, D. E.: Some sources of error in measuring regional blood flow with radioactive microspheres. $J$. Appl. Physiol. 31: 598 (1971).

4. Calcagno, P. L., and Rubin, M. J.: Renal extraction of paraminohippurate in infants and children. J. Clin. Invest., 42: 1632 (1963).

5. Carriere, S., and Biron, P.: Effect of angiotensin 1 on intrarénal blood flow distribution. Amer. J. Physiol., 219: 1642 (1970)

6. Carriere, S., and Friborg, J.: Intrarenal blood flow and PAH extraction during angiotensin infusion. Amer. J. Physiol., 217 : 1708 (1969).

7. Cruskin, A. B., Edelmann, C. M., Jr., and Yuan, S.: Maturational changes in renal blood flow in piglets. Pediat. Res., 4: 7 (1970)

8. Hollenberg, A. C., and Herd, J. A.: The renal circulation. New Engl. J. Med., 47: 455 (1968).

9. Horster, M., and Thurau, K.: Micropuncture studies on the filtration rate of single superficial and juxtamedullary glomeruli in the rat kidney. Pflugers Arch. Gesamte Physiol. Menschen Tiere, 301: 162 (1968).

10. Humphries, M. H., Friedler, R. M., and Early, L. E.: Naturesis produced by vasopressin or hemorrhage during water diuresis in the dog. Amer. J. Physiol., 219: 658 (1970)

11. Jose, P. A., Logan, A. G., Slotkoff, L. M., Lilienfield, L. S.,
Calcagno, P. L., and Eisner, G. M.: Intrarenal blood flow distribution in canine puppies. Pediat. Res., 5: 335 (1971).

12. Katz, M. A., Blantz, R. C., Rector, F, C., Jr, and Seldin, D. W. Measurement of intrarenal blood flow. I. Analysis of microsphere method. Amer. J. Physiol., 220: 1903 (1971).

13. Khambatta, H. J., and Baratz, R. A.: IPPB, plasma ADH, and urine flow in conscious man. J. Appl. Physiol., 33: 362 (1972).

14. Logan A., Jose, P., Eisner, G., Lilienfield, L, and Slotkoff, L. Intracortical distribution of renal blood flow in hemorrhagic shock in dogs. Circ. Res., 29: 257 (1971).

15. McNay, J. L., and Abe, Y.: Pressure-dependent heterogeneity of renal cortical blood flow in dogs. Circ. Res., 27: 571 (1970).

16. Moore, E. S., Satrasook, S. S., Fine, B. P., Katz, M. C., and Edelmann, C. M., Jr.: Renal PAH extraction in puppies (Abstract), p. 119. In: Proceedings of the 39th Annual Meeting, Society for Pediatric Research, Atlantic City, N.J., 1969.

17. Navar, L. G., Guyton, A. C., and Langston, J. B.: Effect of alterations in plasma osmolarity on renal blood flow autoregulation. Amer. J. Physiol., 211: 1387 (1966).

18. Rudolph, A. M., and Heymann, M. A.: Circulation of the fetus in utero: Methods for studying distribution of blood flows, cardiac output and organ blood flow. Circ. Res., 21: 163 (1967).

19. Rudolph, A. M., and Heymann, M. A.: Measurement of flow in perfused organs, using microsphere technique, pp. 112-127. In: Proceedings of the 4th Symposium, Karolinska Symposia on Research Methods in Reproductive Endocrinology, 1971.

20. Sladen, A., Laver, M. B., and Pontoppidan, H.: Pulmonary complications and water retention in prolonged mechanical ventilation. New Engl. J. Med., 279: 448 (1968).

21. Wurtman, R. J.: Catecholamines. New Engl. J. Med., 273: 637 (1965).

22. Model 25601, Nuclear-Chicago, Corporation, Des Plaines, Ill.

23. Bausch and Lomb, Rochester, N.Y.

24. Presented in part at the annual meeting of the Society for Pediatric Research, Atlantic City, May 25, 1972.

25. This research was supported by Public Health Service Grant no. RO-1-HL-13633, Public Health Service General Research Support Grant no. FR 5369, and the State of Illinois.

26. Requests for reprints should be addressed to: E. S. Moore, M.D., Michael Reese Hospital and Medical Center, 2929 S. Ellis Ave. Chicago, Ill. 60616 (USA).

27. Accepted for publication May 2, 1974.

Printed in U.S.A.

Antipyrine placenta

fetus free fatty acids

\title{
Transfer across Perfused Human Placenta. III. Effect of Chain Length on Transfer of Free Fatty Acids
}

\author{
JOSEPH DANCIS, ${ }^{(25)}$ VALERIE JANSEN, HERBERT J. KAYDEN, LORING BJORNSON, \\ AND MORTIMER LEVITZ \\ Departments of Pediatrics, Obstetrics and Gynecology, and Medicine, New York University School of Medicine,
} New York, New York, USA

\section{Extract}

Human placentas were perfused in vitro with straight chain, even-numbered free fatty acids (FFA) and the transfer rates from maternal to fetal circulation were measured. The transfer rates increased logarithmically as chain length decreased. The clearances, calculated as percentage of clearance of antipyrine were: palmitic acid, $4 \%$; myristic acid, $10 \%$; lauric acid, $16 \%$; decanoic acid, 18\%; octanoic acid, 50\%; hexanoic acid, $64 \%$.

Speculation

Transfer of hydrophobic materials through the placenta is a complex process which is probably affected by many factors. The present studies with FFA suggest that, for these compounds, protein binding may be particularly significant. If 
so, it may affect transfer rate by influencing release from maternal serum albumin, diffusion through the placenta, and uptake by fetal plasma. These several factors require further analysis.

We have reported previously (5) on the transfer rate of palmitic acid across human placenta as measured in an in vitro perfusion system. The results suggested that the amounts of free fatty acids (FFA) transferred to the fetus in the last trimester of pregnancy were insufficient for lipid synthesis, which indicated that most of fetal fat was synthesized de novo.

In the present study, we have used essentially the same technique to investigate the effect of chain length on the transfer rate of FFA

\section{METHODS}

\section{PERFUSION TECHNIQUE}

Placentas were obtained immediately after uncomplicated delivery per vaginam or by cesarian and placed in a basin of chilled Earle's buffered salt solution. The cesarians were elective, performed because of previous hysterotomy. A cotyledon was selected and the tributary artery and vein cannulated and perfused with buffered salt solution, previously equilibrated with $95 \% \quad \mathrm{O}_{2}-5 \% \quad \mathrm{CO}_{2}$. The perfused cotyledon was separated from the remaining placenta and a maternal circulation started through small glass cannulas inserted into the intervillous space. The details of the preparatory procedure have been described (12).

\section{EXPERIMENTAL PROCEDURE}

After a brief period of observation, the perfusates were changed to Earle's buffered salt solution containing $1 \mathrm{~g} / 100 \mathrm{~m}$ fat-free serum albumin, either bovine or human. Both maternal and fetal circuits were kept "open," that is, the perfusate was not recirculated. The substances under study were added to the maternal circulation, and the rate of appearance in the fetal perfusate was determined. Antipyrine, $10 \mathrm{mg} / 100 \mathrm{ml}$, or a trace amount of radioactive antipyrine was added routinely to provide a baseline for evaluating the clearances of the test substances. Observations were made for 30-45 min. This permitted the collection of a series of fetal samples demonstrating stability of transfer rate. Clearances were calculated by dividing the product of fetal concentration and flow rate by maternal concentration.

\section{PERFUSATES}

Fat-free bovine serum albumin, $1 \mathrm{~g} / 100 \mathrm{ml}$, in Earle's buffered salt solution, was used in most experiments. For some experiments, defatted human serum albumin was used (4).

The fatty acids were dissolved in a small amount of ethanol with an appropriate amount of radioactive tracer and added to the maternal perfusate in an amount to provide a concentration of $40 \mu \mathrm{M}$. This was done $12 \mathrm{hr}$ before the experiment to permit equilibration with albumin.

\section{ANALYTICAL METHODS}

Radioactivity was determined in a two-channel scintillation spectrometer by adding $0.5 \mathrm{ml}$ perfusate to $10 \mathrm{ml}$ Diotol scintillant (8). In some experiments, $\left({ }^{125} \mathrm{I}\right)$ albumin was also added to the perfusion system to evaluate bulk flow as explained below. In those studies, the FFA were separated from albumin by extraction with ethanol. The ethanol was concentrated under nitrogen and transferred to scintillant. $\left({ }^{125}\right.$ I)Albumin was measured directly in a well scintillation counter.

Antipyrine was determined colorimetrically by the method of Brodie et al. (3). Thin layer chromatography for identification of lipid fractions was carried out on precoated silica gel plates as described previously (5). The concentration of FFA in the human serum albumin was measured colorimetrically as the copper complex (10).

\section{SOLUBILITY IN ORGANIC SOLVENTS}

The partition of FFA between water and the organic solvents, toluene and hexane, was determined. A trace amount of ${ }^{14} \mathrm{C}$-labeled fatty acid was blown to dryness with nitrogen in a test tube. One milliliter of water and $1 \mathrm{ml}$ organic solvent were added to the tube and mixed on a vortex agitater and then centrifugec. One-half milliliter of each layer was transferred to Diotol (8) and the radioactivity determined.

\section{MATERIALS}

Fatty acids were obtained from Applied Science Laboratories $(15)$. The radioactive labeled fatty acids were purchased as follows: from Nuclear-Chicago (16), sodium $\left(1-{ }^{14} \mathrm{C}\right)$ hexanoate, $3.8 \mathrm{mg} / 50 \mu \mathrm{Ci},\left(1^{14} \mathrm{C}\right)$ decanoic acid, 10 $\mathrm{mCi} / \mathrm{mmol},\left(9,10^{-3} \mathrm{H}\right)$ palmitic acid $(\mathrm{N})$ acid, $230 \mathrm{mCi} / \mathrm{mmol}$.

Antipyrine was purchased from Sigma Chemical Company. (17) and antipyrine- $N-\left({ }^{3} \mathrm{H}\right)$ methyl, $170 \mathrm{mCi} / \mathrm{mmol}$ from New England Nuclear (18). Fatty acid-free bovine albumin, type $F$ $(<0.005 \%)$ was obtained from Sigma Chemical Company (17); human albumin, Cohn fraction $V$, from the American Red Cross (19); ${ }^{25}$ I-labeled serum albumin (human), $10 \mu \mathrm{Ci} / \mathrm{ml}$, from Abbott (20). The human albumin was defatted with charcoal (4), with removal of about $90 \%$ of the FFA.

\section{RESULTS}

In each experiment on the transfer rate of FFA, the clearance of antipyrine was simultaneously determined. Differences in antipyrine clearance from placenta to placenta probably reflect physiologic variations and experimental artifacts (12). In reporting the clearances of FFA as percentage of antipyrine clearance, variability among experiments is reduced and comparison with previously reported studies becomes possible (5). Thirteen placentas were successfully perfused. Four additional experiments were rejected because of technical problems.

The clearance of FFA increases logarithmically as the chain length decreases (Fig. 1). Most experiments were done with commercially available bovine serum albumin in the perfusate. "Fat-free" albumin $(<0.005 \%)$ was used to avoid competition for binding with endogenous FFA. In a few experiments fat-free human serum albumin was used and the results indicate the same general relation between chain length of the FFA and clearance (Fig. 1).

The clearance of albumin was measured in seven experiments using ${ }^{125}$ I-labeled human albumin. In four experiments the clearances were $0.01 \mathrm{ml} / \mathrm{min}$, and in three additional experiments, $0.03,0.06$, and $0.12 \mathrm{ml} / \mathrm{min}$. These figures are considerably higher than estimates derived from exchange rates in vivo would suggest (6). It is, therefore, presumed that the clearances for albumin measured in the perfusion system represent primarily bulk flow and are an artifact of the system.

Bulk flows of this magnitude introduce a negligible error into the transfer rates of antipyrine, sodium, and leucine as determined previously (12). However, the clearance of palmitic acid is so low that correction for bulk flow significantly modifies the results. In the present studies, using a correction for bulk flow simultaneously determined with ( ${ }^{25}$ I)albumin, the transfer rate of palmitic acid was $4 \%$ of antipyrine. This is approximately half that previously reported 
(5), which stresses further the inadequacy of maternal supplies of FFA for fetal nutrition. If this figure is inserted into the calculations reported previously, it is estimated that the fetus synthesizes approximately $90 \%$ of its lipids de novo, very similar to Hirsch's estimate derived from analyses of fetal lipids during the last trimester (9).

\section{DISCUSSION}

The present report is part of a continuing study on the transfer of hydrophobic materials across the placenta. Evidence has been presented that the transfer rates for palmitic

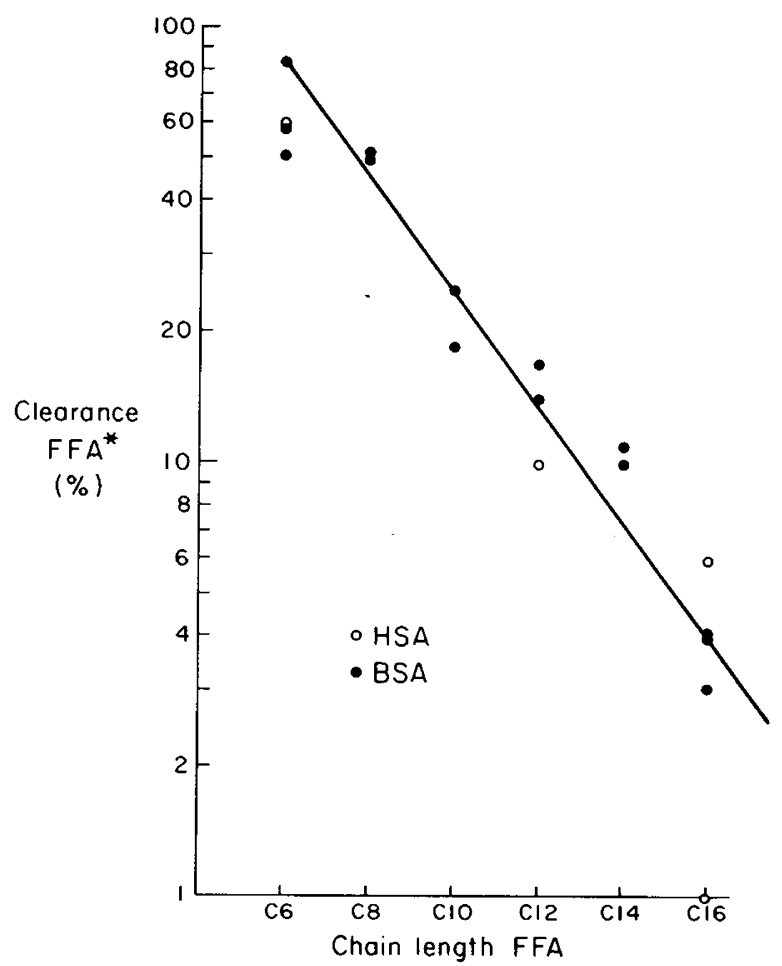

Fig. 1. Clearance of free fatty acid (FFA) as related to chain length. Note logarithmic scale for clearance. Curve drawn by inspection. HSA: human serum albumin; BSA: bovine serum albumin. * percentage of clearance FFA $=\frac{\text { clearance FFA }}{\text { clearance antipyrine }} \times 100$. and linoleic acids, and presumably other long chain fatty acids are inadequate to meet fetal requirements for the deposition of adipose tissue (5). By correcting for bulk flow which is an artifact of the perfusion system the previously reported transfer rate for palmitic acid is reduced to an even lower figure.

The study has now been extended to the medium and short chain fatty acids. These fatty acids do not normally contribute significantly to the diet but they have been used effectively to treat select nutritional problems. When fed as medium chain triglycerides, they are absorbed into the portal vein system as FFA and efficiently metabolized to carbon dioxide by the liver (2). Absorption and metabolism differ significantly from those of the more usual dietary fat constitutents, the long chain triglycerides.

Shortening the carbon chain of the FFA also dramatically changes the placental transfer rate (Fig. 1). A reduction in chain length from palmitic $\left(\mathrm{C}_{16}\right)$ to hexanoic $\left(\mathrm{C}_{6}\right)$ acid increases transfer rate $1600 \%$. The inverse relation of chain length and transfer rate is logarithmic. The shorter chain fatty acids were transferred faster than leucine which has the assistance of an active transport mechanism (5).

The ability of compounds to penetrate membranes is related to their lipid solubility as measured by partition between water and organic solvents (Table 1) $(11,14)$. In general, the more lipophilic the compound, the more readily it penetrates membranes. This has been attributed to the large lipid fraction present in membranes. Under the conditions of the present studies, the reverse was observed; the long chain, more lipophilic FFA were transferred more slowly. Clearly, other factors are more decisive in determining the rate of transfer through the placenta.

The change in molecular size may influence transfer rate. Permeability of membranes to lipophilic materials generally conforms with principles of simple diffusion, and diffusion rates vary inversely with molecular size. However, the magnitude of the effect on lipophilic materials is relatively small (14).

Also implicated in transfer is the binding of materials to circulating plasma proteins. In Table 1 is presented information from the literature on the binding of FFA to albumin. A direct relation is found between protein binding and rates of transfer. A series of binding sites on albumin are available for FFA, and the association constant $\left(\mathrm{K}_{\mathrm{a}}\right)$ for only the first of these is presented. However, the constant at the first site prevides a good index of the strength of binding at the several sites. The larger the $K_{a}$, the smaller the concentration of

Table 1. Relation of transfer rate to chain length, protein binding, and lipid solubility

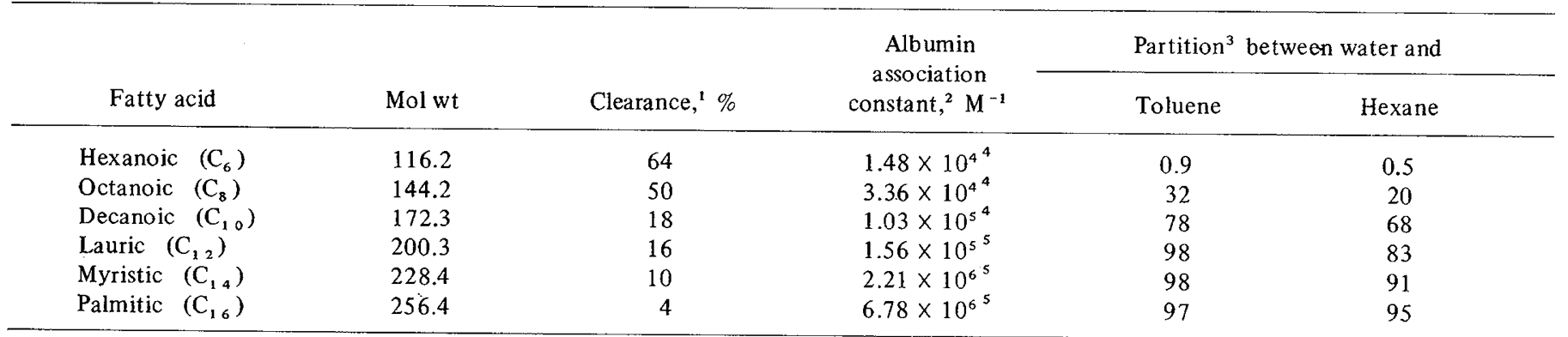

${ }^{1}$ Clearance is expressed as percentage of antipyrine clearance: Clearance free fatty acid (FFA) $\times 100$ Averages of results with bovine serum albumin (Fig. 1).

${ }^{2} \mathrm{~K}_{\mathrm{a}}$ (association or equilibrium constant) $=$ [Protein-FFA complex $]$

${ }^{3}$ Partition $=\frac{\text { cpm FFA in organic solvent }}{\text { cpm FFA in organic solvent }+ \text { water }} \times 100$.

${ }^{4}$ According to the data of Ashbrook et al. (1).

${ }^{5}$ According to the data of Spector et al. (13). 
unbound FFA. $\mathrm{K}_{\mathrm{a}}$ increases 500 -fold between hexanoic and palmitic acids. Protein binding, therefore, provides a logical explanation for transfer rate.

It must be emphasized that correlation does not prove a causal relation. The characteristics defined by albumin binding may reflect the physicochemical nature of the substrate which determines the rate of diffusion through the membrane. It is possible that all of these factors play some role in the transfer rate. Further studies are necessary to evaluate their individual contributions.

\section{SUMMARY}

The transfer of FFA across human placenta has been measured in an in vitro perfusion system. Shortening of the carbon chain of FFA from palmitic acid to hexanoic acid leads to a progressive, logarithmic increase in transfer rate. Changing the lengths of the carbon chain modifies many of the characteristics of the molecule, among them polarity, protein binding, and molecular size. Each of these factors may alter transfer rates at one or more of the major steps in transfer: uptake from maternal plasma, diffusion through the placenta, and release to fetal plasma. Further studies are necessary to separately evaluate the many factors.

\section{REFERENCES AND NOTES}

1. Ashbrook, J. D., Spector, A. A., and Fletcher, J. E.: Medium chain fatty acid binding to human plasma albumin. J. Biol. Chem. 247: 7038 (1972)

2. Borgstrom, B.: Transport of ${ }^{14} \mathrm{C}$-decanoic acid in portal and inferior cava blood during absorption in the rat. Acta Physiol. Scand., 34: 71 (1955).

3. Brodie, B. B., Axelrod, J., Soberman, R., and Levy, B. B.: The estimation of antipyrine in biological materials. J. Biol. Chem., 1 79: 25 (1949).

4. Chen, R. F.: Removal of fatty acids from serum albumin by charcoal treatment. J. Biol. Chem., 242: 173 (1967).

5. Dancis, J., Jansen, V., Kayden, H. J., Schneider, H., and Levitz, M.:
Transfer across perfused human placenta. II. Free fatty acids. Pediat. Res., 7: 192 (1973).

6. Dancis, J., Lind, J., Oratz, M., Smolens, J., and Vara, P.: Placental proteins in human gestation. Amer. J. Obstet. Gynec., 82: 167 (1961).

7. Diamond, J. M., and Wright, E. M.: Biological membranes: The physical basis of ion and nonelectrolyte selectivity. Ann. Rev. Physiol., 31: 581 (1969).

8. Herberg, R. J.: Determination of carbon-14 and tritium in blood and other whole tissues. Anal. Chem., 32: 42 (1960).

9. Hirsch, J., Farquhar, J., Ahrens, E. H., Jr., Peterson, M. L., and Stoffel, W.: Studies of adipose tissue in man, a microtechnic for sampling and analysis. Amer. J. Clin. Nutr., 8: 499 (1960).

10. Laurell, S., and Tibbling, G.: Colorimetric micro-determination of free fatty acids in plasma. Clin. Chem. Acta, 16:57 (1967).

11. Pappenheimer, J. R.: Passage of molecules through capillary walls. Physiol. Rev., 33: 387 (1953).

12. Schneider, H., Panigel, M., and Dancis, J.: Transfer across perfused human placenta of sodium, antipyrine, and leucine. Amer. J. Obstet. Gynec., 114: 822 (1972).

13. Spector, A. A., John, K., and Fletcher, J. E.: Binding of long chain fatty acids to bovine serum albumin. J. Lipid Res., 10: 56 (1969).

14. Wright, E. M., and Diamond, J. M.: Patterns of non-electrolyt permeability. Proc. Royal Soc. Biol., 172: 227 (1969).

15. NCS Amersham-Searle Corporation, Arlington Heights, Ill.

16. Applied Science Laboratories, State College, Penn.

17. Nuclear-Chicago (NCS Amersham-Searle Corporation, Arlington Heights, Ill.).

18. Sigma Chemical Company, St. Louis, Mo.

19. New England Nuclear, Boston, Mass.

20. American Red Cross, Greater New York Blood Program, New York, N. Y.

21. Abbott Laboratories, North Chicago, Ill.

22. Maternal consent was obtained to study placenta.

23. Dr. J. Dancis is a recipient of a Career Research Award, National Institutes of Health, Grant no. 5-K6-HD-16710.

24. This research was supported by NIH Grants no. 5-R01 HD00462 and 5 R01 CA02071-19 and United States Public Health Service Grant no. HE0-6481.

25. We are indebted to Elizabeth Miller for technical assistance.

26. Requests for reprints should be addressed to: J. Dancis, M.D. Department of Pediatrics, New York University Medical Center, 550 First Ave., New York, N. Y. 10016 (USA).

27. Accepted for publication May 6, 1974. 